Katarzyna Ś WierczewSKa-Pietras

Uniwersytet Pedagogiczny im. Komisji Edukacji Narodowej w Krakowie

\title{
Inwestycje w infrastrukturę informatyczną podmiotów gospodarczych dzialających na poprzemysłowym obszarze objętym Lokalnym Programem Rewitalizacji Zabłocia w Krakowie
}

Celem artykułu jest analiza infrastruktury informatycznej w Polsce oraz przedstawienie wyników badań dotyczących inwestycji w infrastrukturę informatyczną podmiotów gospodarczych działających na poprzemysłowym obszarze objętym Lokalnym Programem Rewitalizacji Zabłocia w Krakowie. Badanie zostało przeprowadzone w 2008 r. na adresowej próbie 100 przedsiębiorstw działających na obszarze Zabłocia, wylosowanych na podstawie numeru statystycznego podmiotu gospodarczego REGON. W analizie obszaru zostały również wykorzystane badania przeprowadzone w 2008 r. przez Instytut Badań Rynku i Opinii Publicznej (CEM) na zlecenie Urzędu Miasta Krakowa. W celu dokonania analizy na poziomie ogólnopolskim zostały wykorzystane wyniki badań statystycznych „Społeczeństwo informacyjne w Polsce” z lat 2000-2007.

\section{INFRASTRUKTURA INFORMATYCZNA}

Warunkiem budowania potencjału firm w okresie dynamicznie rozwijającej się gospodarki jest tworzenie rozwiązań wpływających na ich konkurencyjność. W dobie nowych technologii, gdzie czas odgrywa istotną rolę w procesie kontaktów z klientem, sprzedażą usług czy transferem danych, komputery, Internet oraz zaawansowane technologicznie systemy komputerowe zarządzające pracą przedsiębiorstw stają się nieodłącznym elementem funkcjonowania sektora MSP. Wyniki badań statystycznych „Społeczeństwo informacyjne w Polsce"1 z lat 2000-2007, przeprowadzonych przez Główny Urząd Statystyczny, wskazu-

${ }^{1}$ GUS przeprowadził serię badań dotyczących wykorzystania technologii informacyjno-telekomunikacyjnych (ICT) na grupie 14000 przedsiębiorstw oraz badania pilotażowe wykorzystania ITC w przedsiębiorstwach sektora finansowego na grupie 1500 przedsiębiorstw. Liczba pracujących w sektorach wyniosła od 10 do więcej osób. Badanie zostało przeprowadzone metodą reprezentacyjną. W latach 2004-2005 w badaniu uczestniczyło 79\% przedsiębiorstw wybranych do próby, a w 2007 r. 83\%. 
ją, iż 95\% przedsiębiorstw wykorzystywało w 2007 r. w swojej codziennej pracy komputery, a dostęp do Internetu posiadało 93\% firm. Internet służył przedsiębiorstwom do korzystania z usług bankowych (72\%), do kontaktów z administracją publiczną (64\%), monitorowania rynku (45\%), szkolenia pracowników (26\%), dokonywania zakupów (22\%) czy prowadzenia sprzedaży on-line (9\%). Swoją stronę internetową posiadało 53\% przedsiębiorstw. Jak wynika z powyższych badań, komputery i Internet stały się narzędziem biznesowym wykorzystywanym przez firmy przy rozliczeniach finansowych, realizacji sprzedaży, przesyłaniu i przekazywaniu informacji, promocji, reklamie, poszukiwaniu dostawców, rozpoznawaniu konkurencji.

Pierwsze badanie na temat „Wykorzystania technologii informacyjno telekomunikacyjnych w przedsiębiorstwach” przeprowadzono w Polsce w 2004 r. Dane Głównego Urzędu Statystycznego wskazują, iż wzięło w nim udział ponad 6 tys. firm działających na obszarze całego kraju. W krajach Unii Europejskiej podobne badania przeprowadzane są od 2001 r. na podstawie opracowanego kwestionariusza przez urzędy statystyczne państw Wspólnoty oraz Urząd Statystyczny UE-Eurostat i przy wsparciu finansowym Komisji Europejskiej. Polska w analizowanych danych za 2007 r. znajduje się na 22 miejscu (95\%) wśród krajów Wspólnoty, w których przedsiębiorstwa wykorzystują komputery do codziennej pracy. Największe wykorzystanie zanotowano w Holandii (100\%), Słowacji, Francji i Finlandii (99\%), najmniejsze w Rumunii (82\%), Bułgarii (85\%), na Litwie i Węgrzech (91\%).

Obecnie uważa się, iż wyposażenie przedsiębiorstw w instrumenty infrastruktury informatycznej wpływa na bezpieczeństwo, obniżenie kosztów oraz zwiększenie wydajności pracy. Posiadanie przez firmy komputerów jest postrzegane jako główna cecha charakteryzująca rozwój społeczeństwa informacyjnego.

\section{WYKORZYSTANIE KOMPUTERÓW W PRACY SEKTORA MSP}

Na podstawie analizy przeprowadzonych badań przez GUS za lata 2004-2007 można stwierdzić, iż najwięcej komputerów wykorzystują duże i średnie przedsiębiorstwa (100\%). W małych przedsiębiorstwach wskaźnik wykorzystania komputerów wynosi 94\% za 2007 r. (zauważa się wyraźny wzrost o 3 punkty procentowe w stosunku do 2004 r.).

Biorąc pod uwagę wykorzystanie przez przedsiębiorstwa komputerów według województw w Polsce, stwierdza się, iż największe wykorzystanie występuje w województwie podkarpackim i opolskim 98\%, najmniejsze w podlaskim 90\%. W województwie małopolskim wskaźnik wykorzystania wynosi 94\% (zob. ryc. 1). Niestety, na dzień dzisiejszy nie ma dostępnych danych dotyczących wykorzystania komputerów w przedsiębiorstwach dla Gminy Miejskiej Kraków. Urząd Statystyczny w Krakowie prowadzi badania dla całego województwa. 


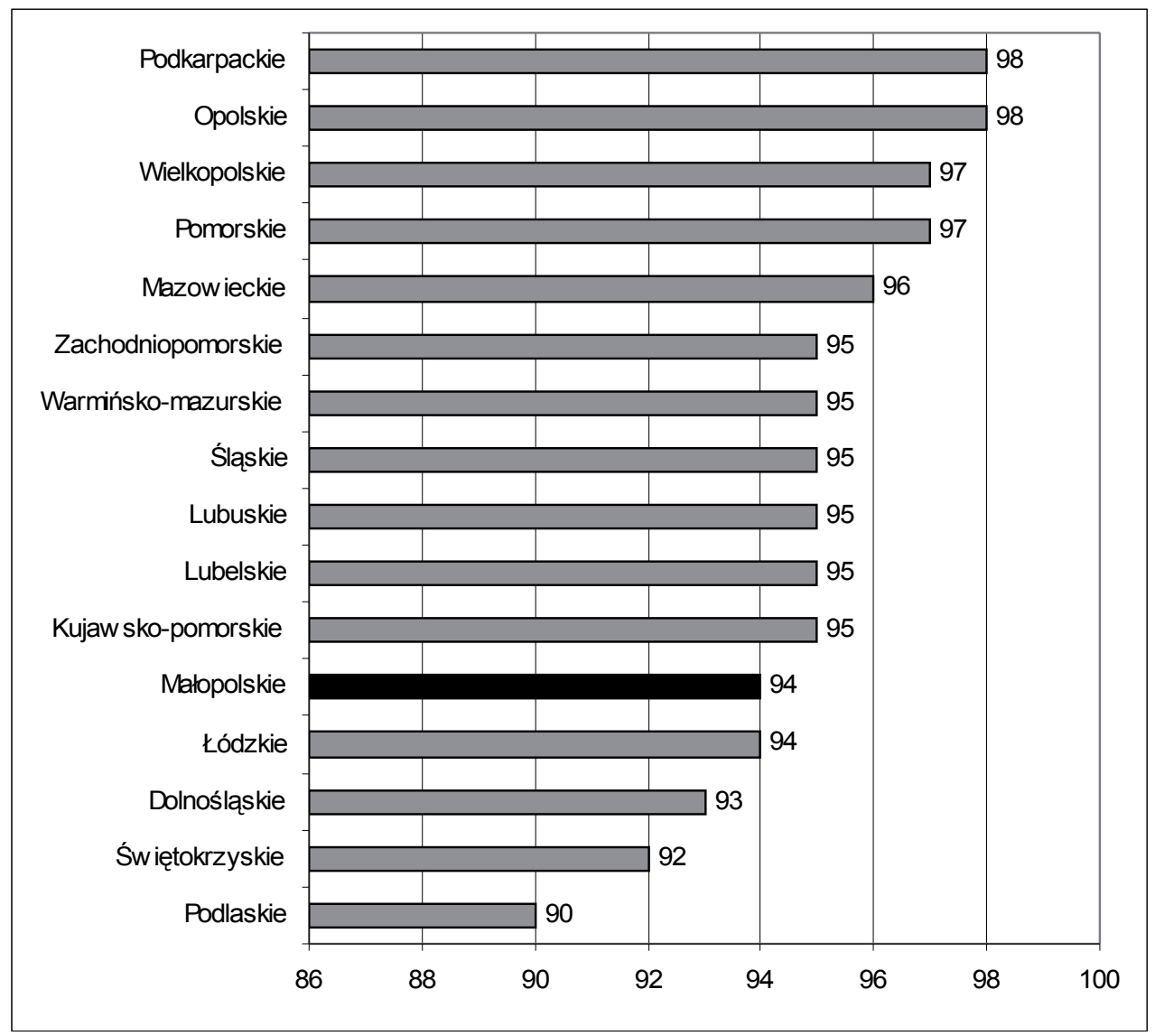

Ryc. 1. Wykorzystanie komputerów przez przedsiębiorstwa według województw w 2007 r.

Źródło: opracowanie własne na podstawie danych z GUS

\section{SIEĆ INTERNET JAKO NARZĘDZIE PRACY SEKTORA MSP}

Kolejnym instrumentem infrastruktury informatycznej wykorzystywanym w codziennej pracy przez przedsiębiorstwa jest Internet. Narzędzie to pozwala zaistnieć firmom na rynku globalnym, zdobyć potencjalnych kontrahentów, umożliwia szybki kontakt z klientami, wymianę danych czy reklamę. Posiadanie przez firmę strony internetowej staje się nieodłącznym elementem prowadzenia działalności gospodarczej.

Początki biznesu elektronicznego w Polsce sięgają lat 90. XX w. Wówczas przedsiębiorcy tworzyli swoje pierwsze strony internetowe jako wizytówki prowadzonej działalności gospodarczej. Obecnie niektórzy założyli sklepy internetowe bądź korzystają z aukcji internetowych. Wyniki badań Eurostatu za 2007 r. wskazują, iż Polska znajduje się na 22 miejscu wśród krajów Wspólnoty, w których przedsiębiorstwa wykorzystują do codziennej pracy Internet. 


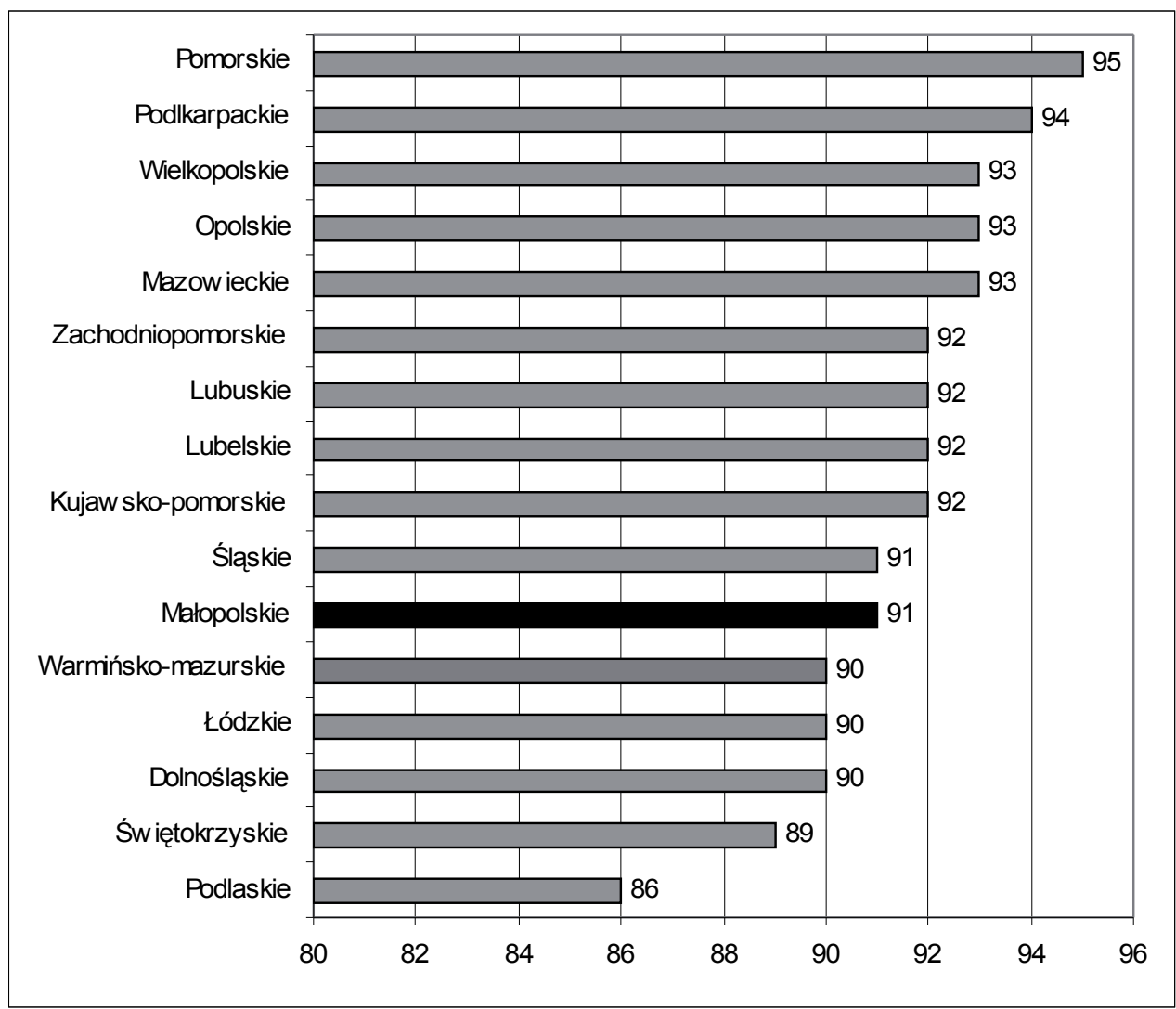

Ryc. 2. Wykorzystanie Internetu w przedsiębiorstwach według województw w 2007 r.

Źródło: opracowanie własne na podstawie danych z GUS

Największe wykorzystanie sieci występuje w województwie pomorskim (95\%), jak również podkarpackim (94\%), wielkopolskim, opolskim i mazowieckim (93\%), najmniejszy odsetek wykazują województwa podlaskie (86\%), świętokrzyskie (89\%), dolnośląskie, łódzkie i warmińsko-mazurskie (90\%). W województwie małopolskim korzystano z sieci w przedsiębiorstwach w 2007 r. na poziomie 91\% (por. ryc. 2). Na chwilę obecną brak jest danych o wykorzystaniu Internetu w przedsiębiorstwach w Gminie Miejskiej Kraków.

Jak wynika z badań GUS, w 2004 r. 52\% przedsiębiorstw korzystało z połączeń z Internetem poprzez modem analogowy, $28 \%$ poprzez stałe połączenia szerokopasmowe, natomiast 8\% poprzez połączenia bezprzewodowe (wąsko- i szerokopasmowe). W $2007 \mathrm{r}$. przedsiębiorstwa łączyły się w większości przez stałe połączenia szerokopasmowe (53\%), modem analogowy (30\%) oraz połączenia bezprzewodowe $(20 \%)$.

Analiza powyższych danych wskazuje, iż największy odsetek wykorzystania Internetu występuje w przedsiębiorstwach zajmujących się pośrednictwem finansowym, działalnością filmową, radiową i telewizyjną oraz informatyką. W najmniejszym stopniu Internet wykorzystują firmy z sektora przetwórstwa przemysłowego oraz budownictwa, jednak w $2007 \mathrm{r}$. w stosunku do roku 2004 r. powyższe branże zanotowały wzrost odsetka przedsiębiorstw 
wykorzystujących Internet. Dla budownictwa nastąpił wzrost o 12 punktów, natomiast w przetwórstwie przemysłowym zanotowano wzrost o 7 punktów. Największy 15-punktowy wzrost w 2007 r. w wykorzystaniu sieci zanotowało hotelarstwo i inne obiekty noclegowe turystyki.

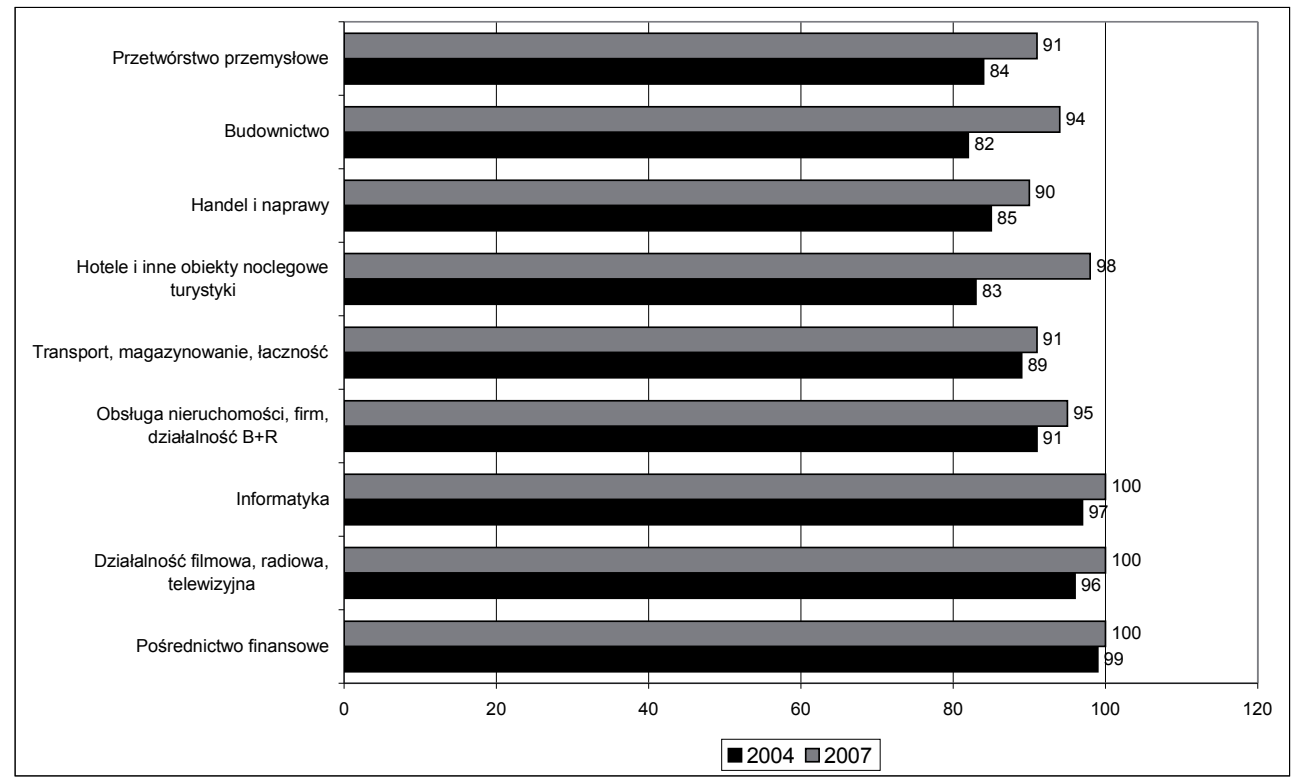

Ryc. 3. Wykorzystanie sieci Internet w przedsiębiorstwach w roku 2004 i 2007 według rodzaju działalności

Źródło: opracowanie własne na podstawie danych z GUS

\section{STRONA INTERNETOWA JAKO GLOBALNY INSTRUMENT KOMUNIKACJI SEKTORA MSP}

Wizytówką firmy, która chce zaistnieć na rynku globalnym, jest strona www. Służy ona jako narzędzie do przedstawienia oferty, kontaktów z kontrahentami czy wymiany informacji. Jak wynika z badań GUS, ponad połowa przedsiębiorstw w 2007 r. posiadała swoją stronę internetową. Najwięcej firm posiadających własną stronę internetową to firmy duże (87\%), najmniej firmy małe (47\%). Małe przedsiębiorstwa zajmujące się głównie handlem nie inwestują w założenie stron, ponieważ ich oferta skierowana jest głównie do klientów regionalnych.

Najmniejszy odsetek przedsiębiorstw posiadających stronę www odnotowano w $2007 \mathrm{r}$. w branży budowlanej (44\%). Jednak w stosunku do 2004 r. nastąpił wzrost o 10 punktów. Firmy z branży budowlanej opierają się głównie na przetargach i reklamie klientów indywidualnych. Działalność finansowa, radiowa i telewizyjna wymaga natomiast zaistnienia w sieci, dlatego największy odsetek (87\% w 2007 r.) firm z tego sektora posiada stronę internetową. 


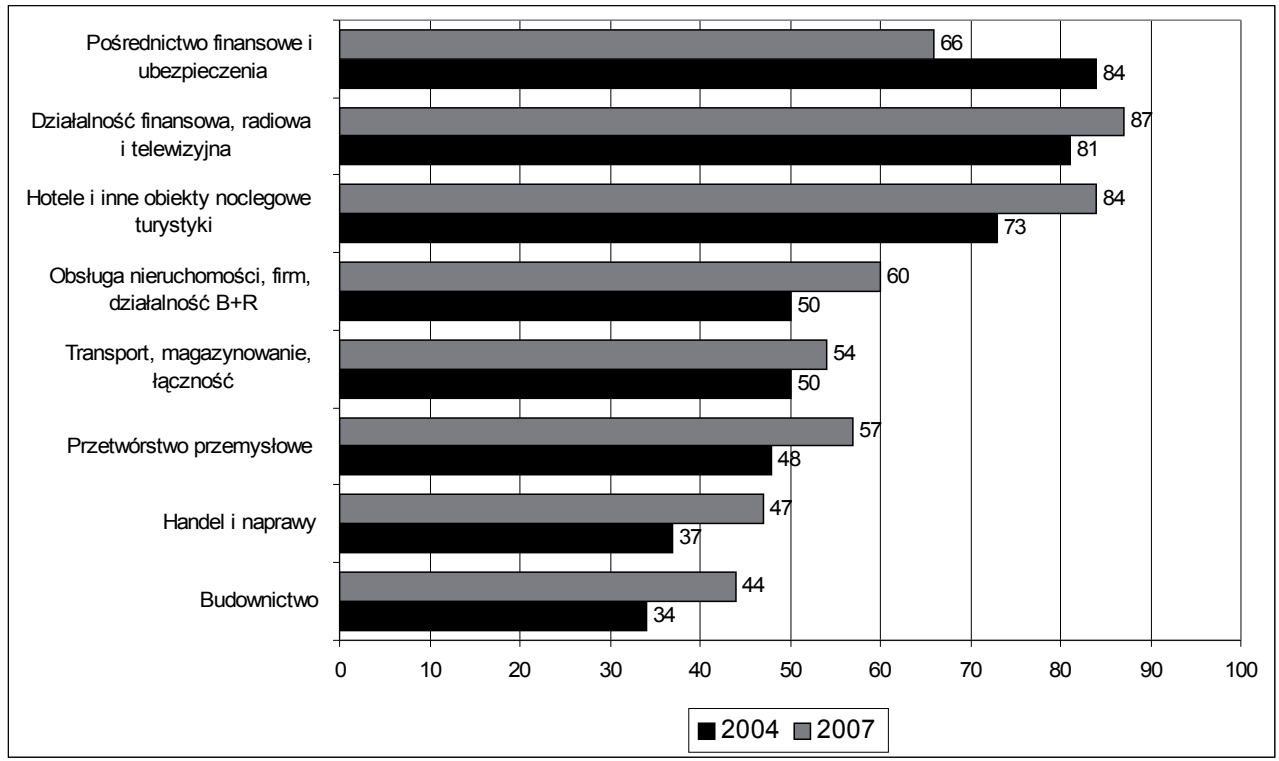

Ryc. 4. Przedsiębiorstwa posiadające strony www z podziałem na lata 2004 i 2007 oraz rodzaj prowadzenia działalności gospodarczej

Źródło: opracowanie własne na podstawie danych z GUS

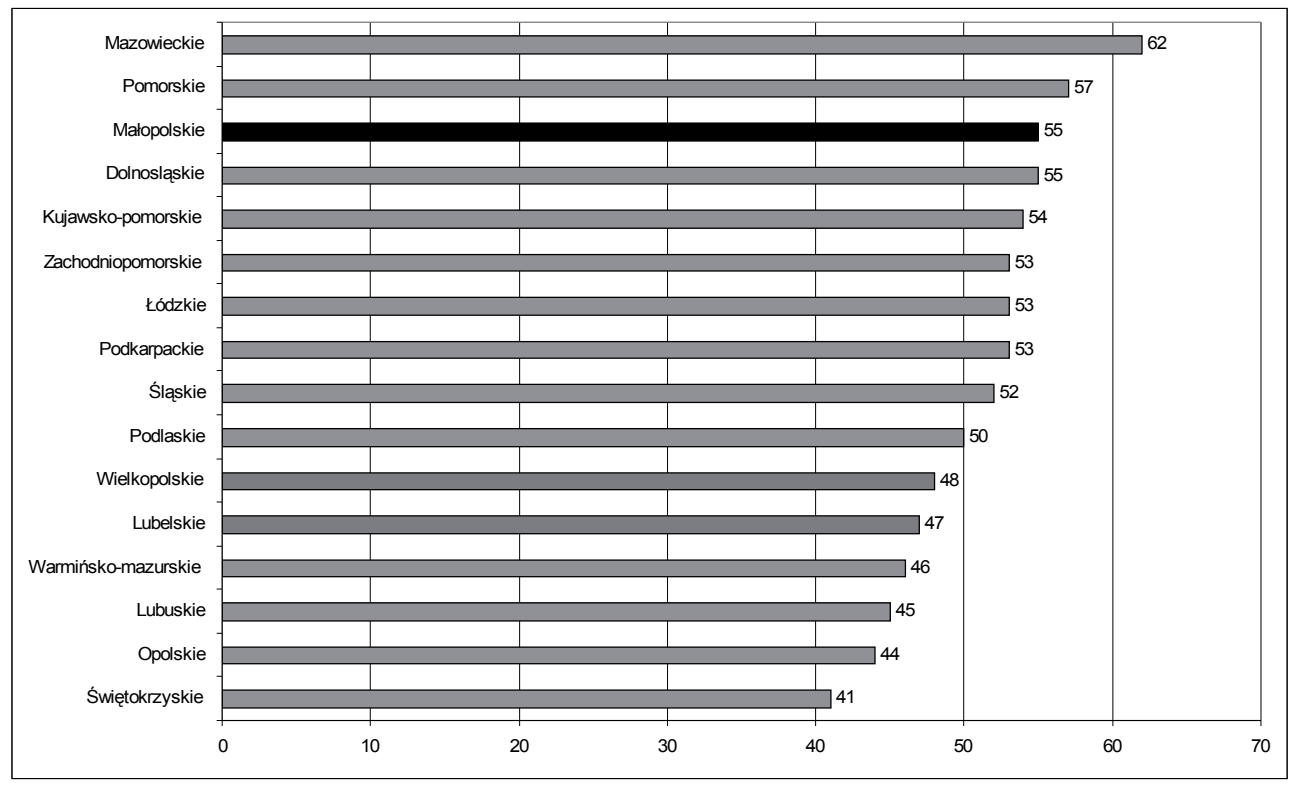

Ryc. 5. Przedsiębiorstwa posiadające stronę internetową według województw Źródło: GUS 
Województwo małopolskie z 55 punktami uplasowało się w czołówce województw, w których przedsiębiorstwa posiadają własna stronę internetową. Najmniejszy odsetek zanotowano w województwie świętokrzyskim (41\%), opolskim (44\%) oraz lubuskim (45\%).

Jak wynika z badań, firmy bez względu na wielkość i rodzaj prowadzonej działalności gospodarczej najczęściej wykorzystują strony internetowe do promocji towarów i usług. W 2007 r. z tej formy promocji skorzystało 48\% firm w Polsce. Co trzecie przedsiębiorstwo używa stron www w celu ułatwienia dostępu do katalogów produktów lub cenników.

\section{STRUKTURA GOSPODARKI LOKALNEJ I WYKORZYSTANIE WYSOKICH TECHNOLOGII PRZEZ PRZEDSIĘBIORCÓW DZIAŁAJĄCYCH NA POPRZEMYSŁOWYM OBSZARZE ZABŁoCIA W KraKowIE}

Zabłocie to historyczny obszar Krakowa usytuowany na prawym brzegu Wisły. Granice obszaru zostały określone zarówno w Miejscowym Planie Zagospodarowania Przestrzennego (uchwalonym w czerwcu 2006 r.), jak również w Lokalnym Programie Rewitalizacji (uchwalonym w październiku 2006 r.).

Zabłocie swój poprzemysłowy charakter zawdzięcza lokalizacji w XIV w. portu i składu solnego, licznych fabryk i mniejszych zakładów produkcyjnych działających na przełomie XIX i XX w. Do najważniejszych można zaliczyć m.in. powstałą w 1949 r. fabrykę słodyczy i wyrobów cukierniczych (obecnie „Wawel”), fabrykę zapałek „Znicz”, na miejscu której powstała Huta Szkła w Krakowie, produkująca butelki na potrzeby Państwowego Monopolu Spirytusowego (obecnie po przekształceniach Instytut Szkła i Ceramiki), fabrykę dachówek Azbestowych „Evaritas” czy najbardziej znaną fabrykę Naczyń Emaliowanych i Wyrobów Blaszanych „Rekord” (obecnie fabryka Oskara Schindlera), która produkowała sprzęt na potrzeby armii niemieckiej. Na obszarze Zabłocia mieściła się również fabryka mydła, przekształcona w latach 50. XX w. w Krakowską Fabrykę Kosmetyków „Miraculum” i garbarnia „Progress”, w której obecnie znajdują się pomieszczenia biurowo-handlowe.

Układ komunikacyjny Zabłocia przyczynił się do wprowadzenia w mpzp Zabłocia podziału funkcjonalno-przestrzennego na trzy części: A - Stare Podgórze, B - Stare Zabłocie, C-Zabłocie Wschód.

W części A dominuje zabudowa mieszkalno-usługowa, silnie związana z historią Starego Podgórza. Przy mieszczącej się w obszarze ul. Na Zjeździe znajduje się plac Bohaterów Getta, z którego podczas II wojny światowej transportowano ludność żydowską do obozów zagłady. W 2006 r. plac został oddany do użytku po generalnym remoncie. Jest to pierwszy zrealizowany projekt rewitalizacyjny w obszarze, który stanowi jednocześnie swoistego rodzaju pomnik upamiętniający wydarzenia wojenne. W 2006 r. plac został wyróżniony w konkursie European Prize for Urban Public Space. W część B, czyli tzw. Starego Zabłocia, znajdują się głównie małe i średnie przedsiębiorstwa z zabudową magazynowo-biurową. Część C obejmuje w większości tereny Chemobudowy i ogródków działkowych.

Według danych Urzędu Statystycznego liczba podmiotów działających na obszarze Zabłocia wynosi ok. 700, co stanowi 7\% ogólnej liczby podmiotów zarejestrowanych na obszarze miasta, z liczbą zatrudnionych do 9 i mniej osób. 


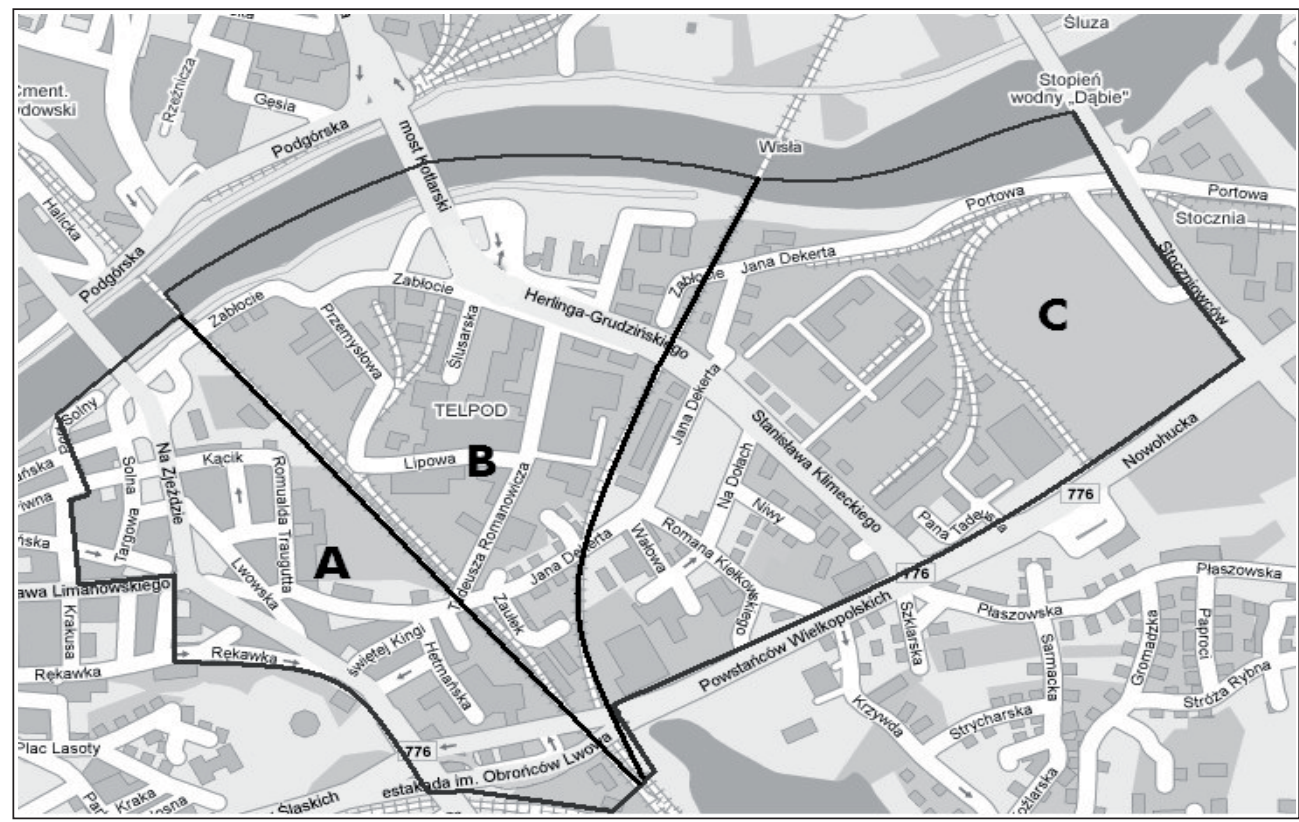

Ryc. 6. Mapa obszaru objętego Lokalnym Programem Rewitalizacji Zabłocia (LPR) i Miejscowym Planem Zagospodarowania Przestrzennego (mpzp)

Źródło: opracowanie własne na podstawie google maps

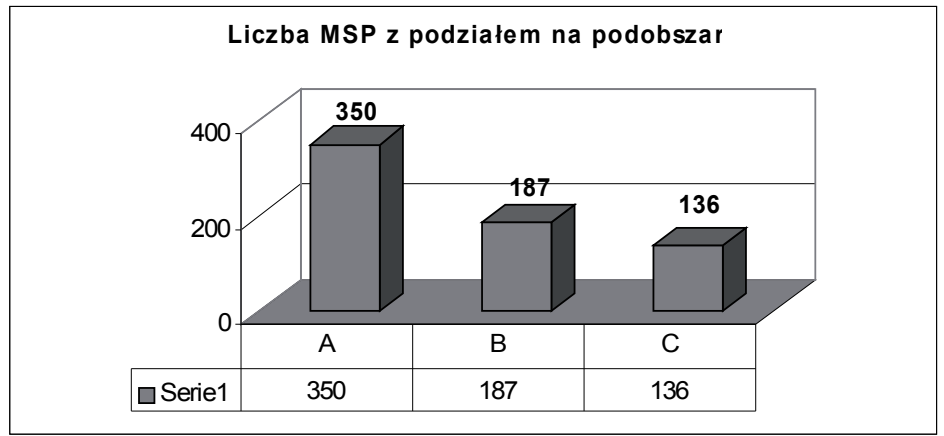

Ryc. 7. Liczba MSP z podziałem na podobszary

Źródło: opracowanie własne na podstawie danych Urzędu Statystycznego

Najwięcej firm znajduje się w sektorze A z liczbą 350 podmiotów gospodarczych zarejestrowanych w bazie REGON. W części B zarejestrowano 190 firm. Są to w większości obiekty magazynowo-biurowe. Natomiast część C z liczbą 140 podmiotów zdominowana jest przez dwunastohektarową działkę Chemobudowy, mieszczącej centrum targowo-wystawiennicze oraz liczne hurtownie, magazyny i punkty usługowe. W ostatnich latach liczba firm sukcesywnie wzrasta, obszar Zabłocia uważany jest za jeden z najbardziej atrakcyjnych rejonów Krakowa. 


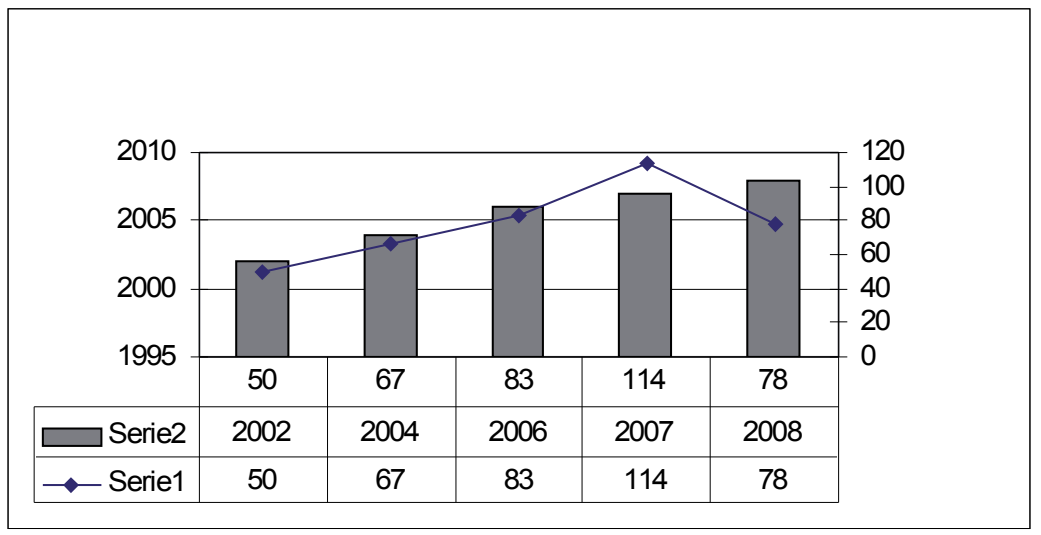

Ryc. 8. Liczba MSP rozpoczynających działalność na obszarze objętym LPR Zabłocia $\mathrm{z}$ podziałem na lata

Źródło: opracowanie własne na podstawie danych z Urzędu Statystycznego

Z badań przeprowadzonych przez CEM wynika, iż na obszarze Zabłocia znajduje zatrudnienie 6330 pracowników, co stanowi ok. 4\% ogólnej liczby zatrudnionych w sektorze przedsiębiorstw w Krakowie. Najwięcej pracowników zatrudniają małe i średnie przedsiębiorstwa działające w przedziale od 0-9 (41\%), a najmniej od 250-999 (por. ryc. 9).

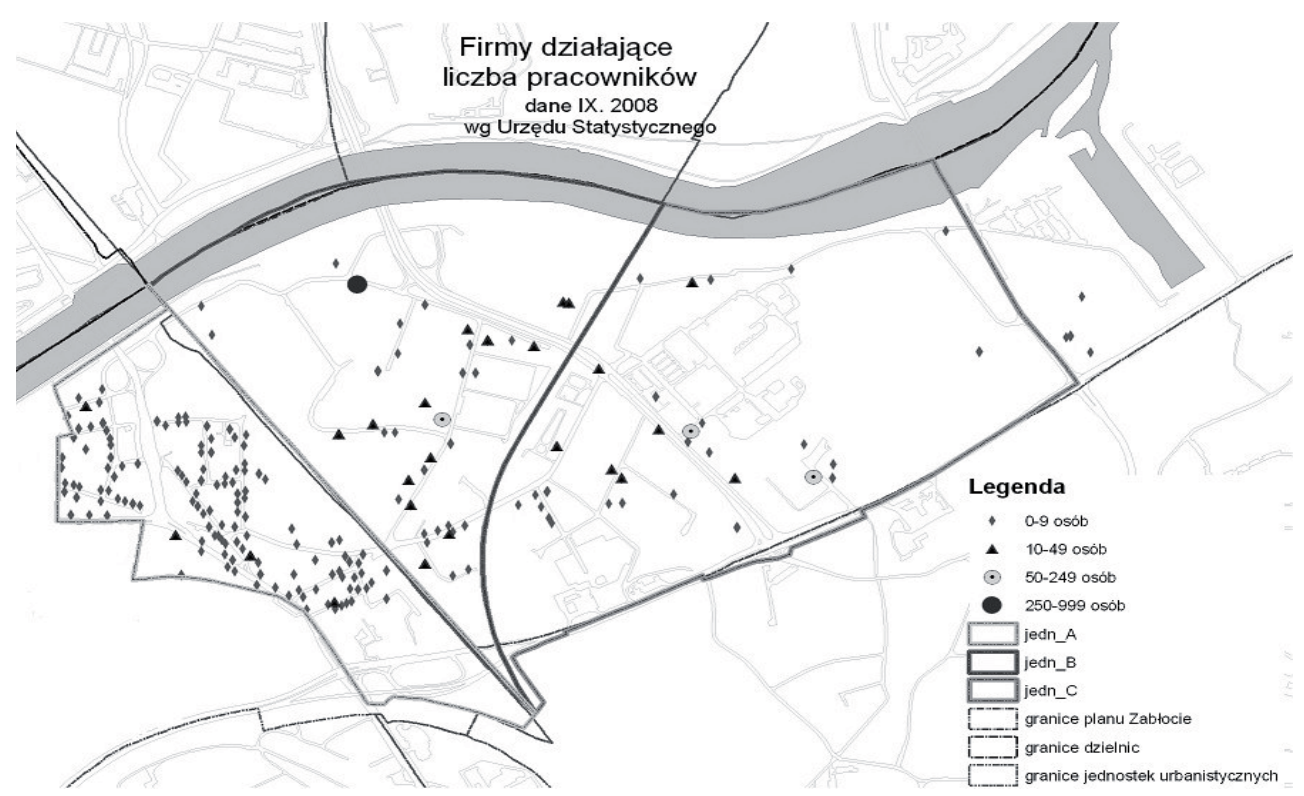

Ryc. 9. Liczba pracowników zatrudnionych w poszczególnych sektorach A, B, C Źródło: Urząd Miasta Krakowa 


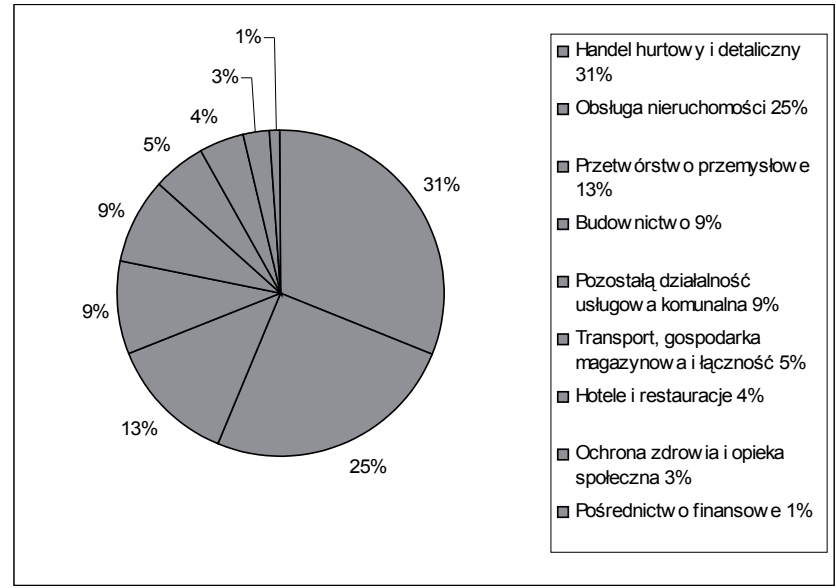

Ryc. 10. Struktura MSP według wybranych sekcji PKD w 2007 r.

Źródło: opracowanie własne na podstawie danych z Urzędu Statystycznego

Na obszarze Zabłocia przeważają przedsiębiorstwa $\mathrm{z}$ branży handel hurtowy i detaliczny $(31 \%)$, obsługa nieruchomości $(25 \%)$ oraz przetwórstwo przemysłowe. Najmniej firm zajmuje się pośrednictwem finansowym (1\%).

\section{WYKORZYSTANIE KOMPUTERÓW W PRACACH SEKTORA MSP}

Jak wynika z badań przeprowadzonych przez CEM na zlecenie Urzędu Miasta Krakowa, ponad jedna trzecia przedsiębiorstw działających na obszarze Zabłocia posiada więcej niż dwa komputery, natomiast więcej niż 10 posiada 24\% ankietowanych. Komputerów nie posiada 6\% badanych, a 9\% deklaruje, iż dysponuje 1 komputerem. Najwięcej komputerów posiadają firmy zatrudniające ponad 10 pracowników (98\%).

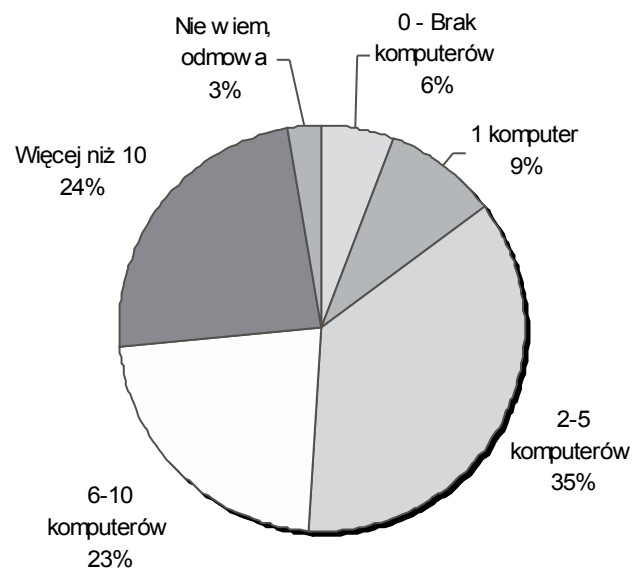

Ryc. 11. Liczba komputerów w przedsiębiorstwie Źródło: CEM 


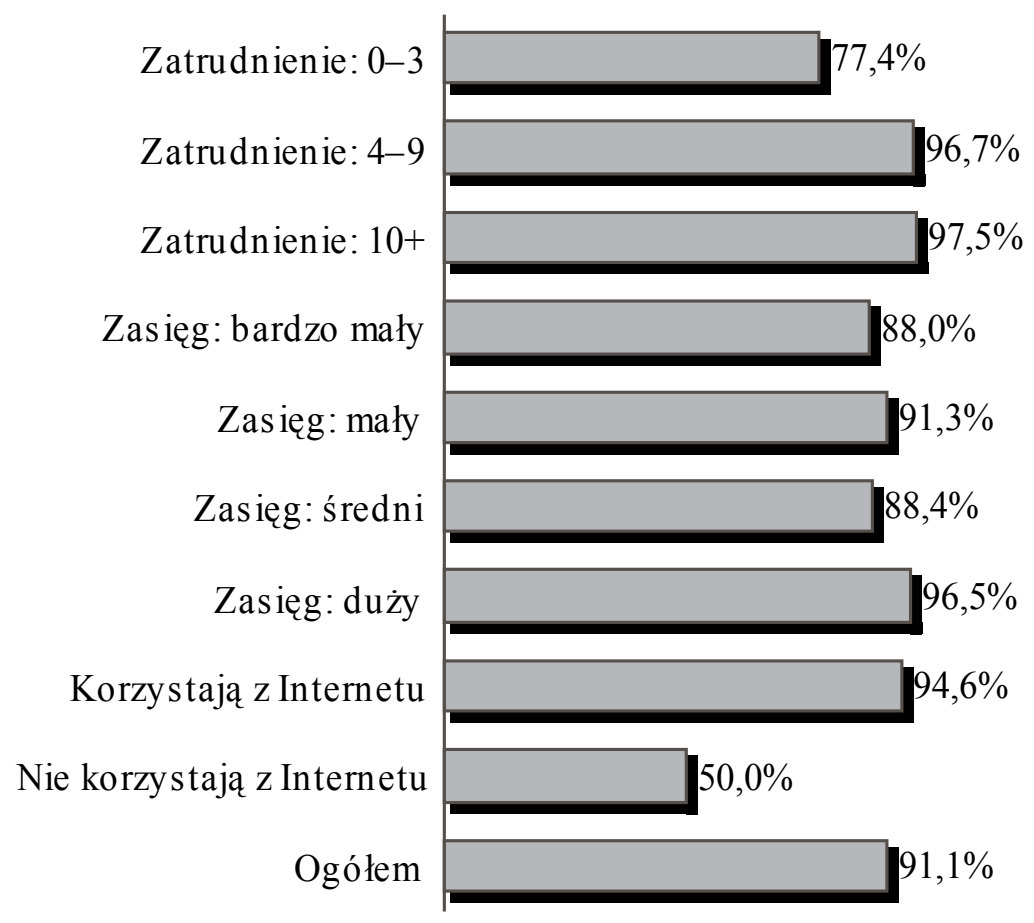

Ryc. 12. Firmy posiadające komputery

Źródło: CEM

Z omawianych badań wynika, iż najwięcej firm (ok. 80\%) mających swoją siedzibę na obszarze Zabłocia zainwestowało w 2008 r. w infrastrukturę informatyczną, zakup lub modernizację komputerów/oprogramowania, z czego ponad 90\% korzysta z Internetu podczas codziennej pracy. Na drugim miejscu znalazła się modernizacja maszyn lub urządzeń. Z powyższych danych wynika, iż w dobie codziennej rynkowej konkurencji firmy starają się usprawniać system działania obejmujący komunikację wewnętrzną i zewnętrzną nastawioną na klienta.

$\mathrm{Z}$ analizy badań wynika również, iż firmy planują w najbliższej przyszłości dalsze inwestycje. Najwięcej firm korzystających z komputerów i Internetu zajmuje się nieruchomościami, doradztwem, konsultingiem oraz reklamą.

\section{WYKORZYSTANIE SIECI INTERNET PRZEZ PRZEDSIĘBIORSTWA} DZIAŁAJĄCE NA OBSZARZE ZABŁOCIA

Z przeprowadzonych badań wynika, iż 92\% przedsiębiorstw wykorzystuje w swojej codziennej pracy Internet. Analogicznie do badań przeprowadzonych przez GUS dla terenu całej Polski, można stwierdzić, iż na obszarze Zabłocia najwięcej z Internetu korzystają firmy średnie i duże, zatrudniające powyżej 10 pracowników. 


\section{Czy korzystają Państwo z internetu?}

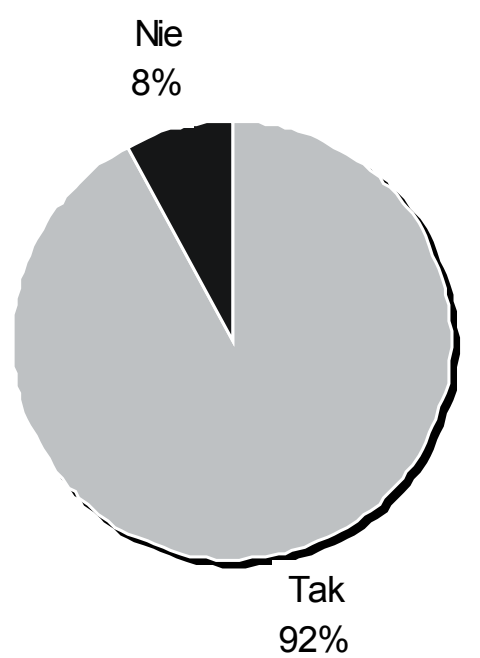

Ryc. 13. Wykorzystanie sieci Internet w codziennej pracy

Źródło: CEM

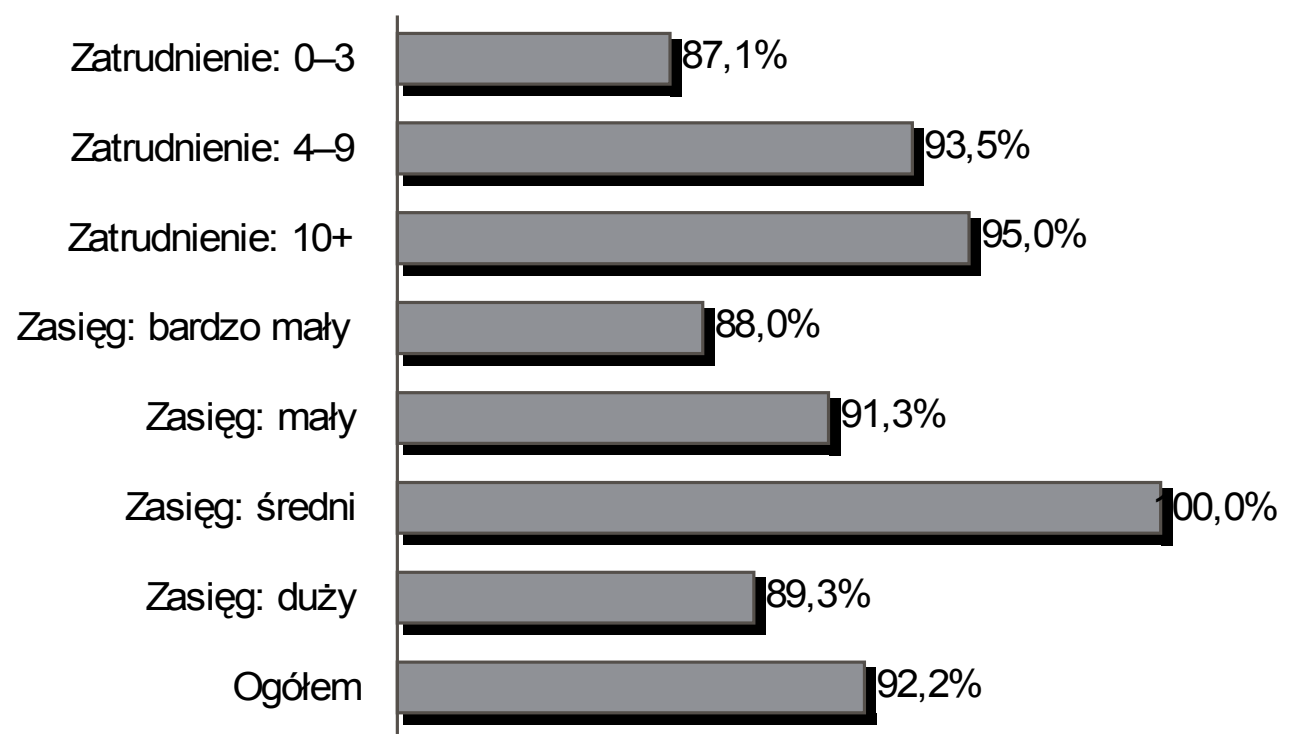

Ryc. 14. Firmy korzystające $\mathrm{z}$ Internetu 


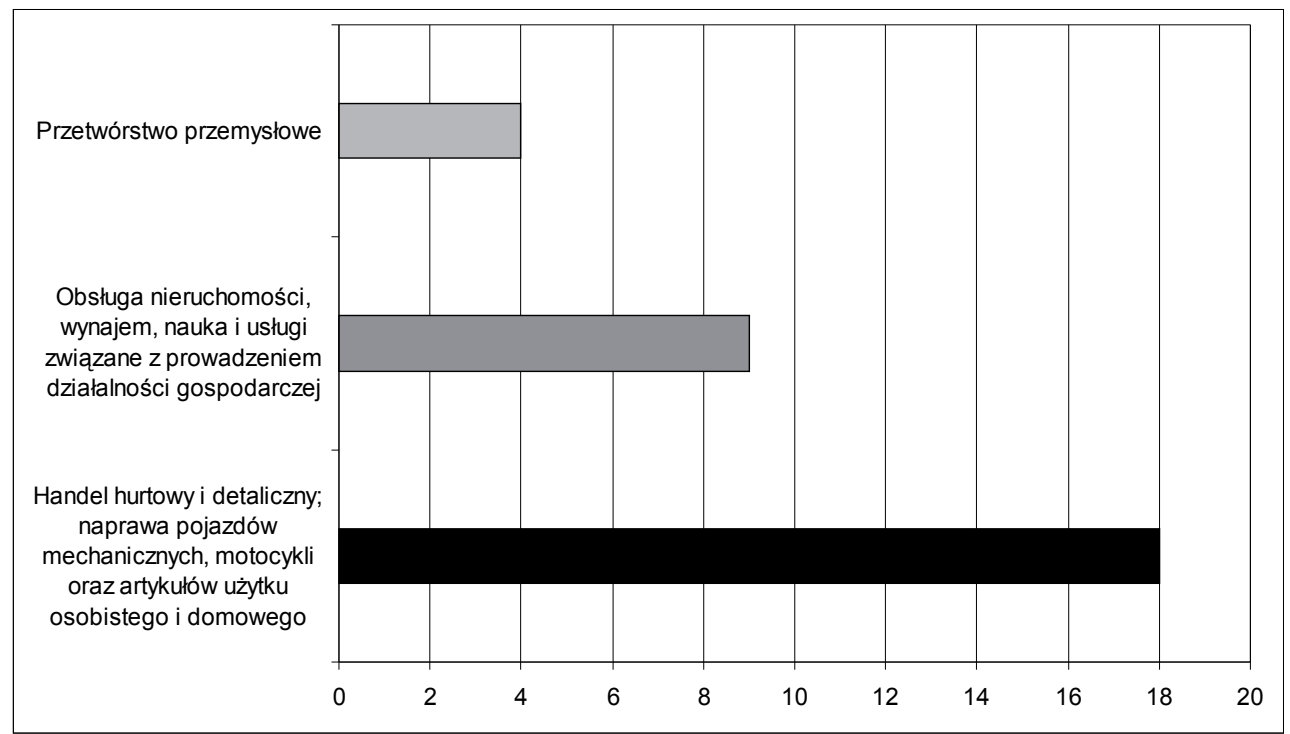

Ryc. 15. Wykorzystanie sieci Internet do reklamy firmy z podziałem na branże wg sekcji PKD

Źródło: opracowanie autorki na podstawie danych z badań własnych

Ponad $60 \%$ firm działających na obszarze Zabłocia nie wykorzystuje sieci Internet do przedstawienia swojej oferty. Produkty reklamuje jedna trzecia ankietowanych, a własną stronę internetową posiada tylko 3\% badanych przedsiębiorstw.

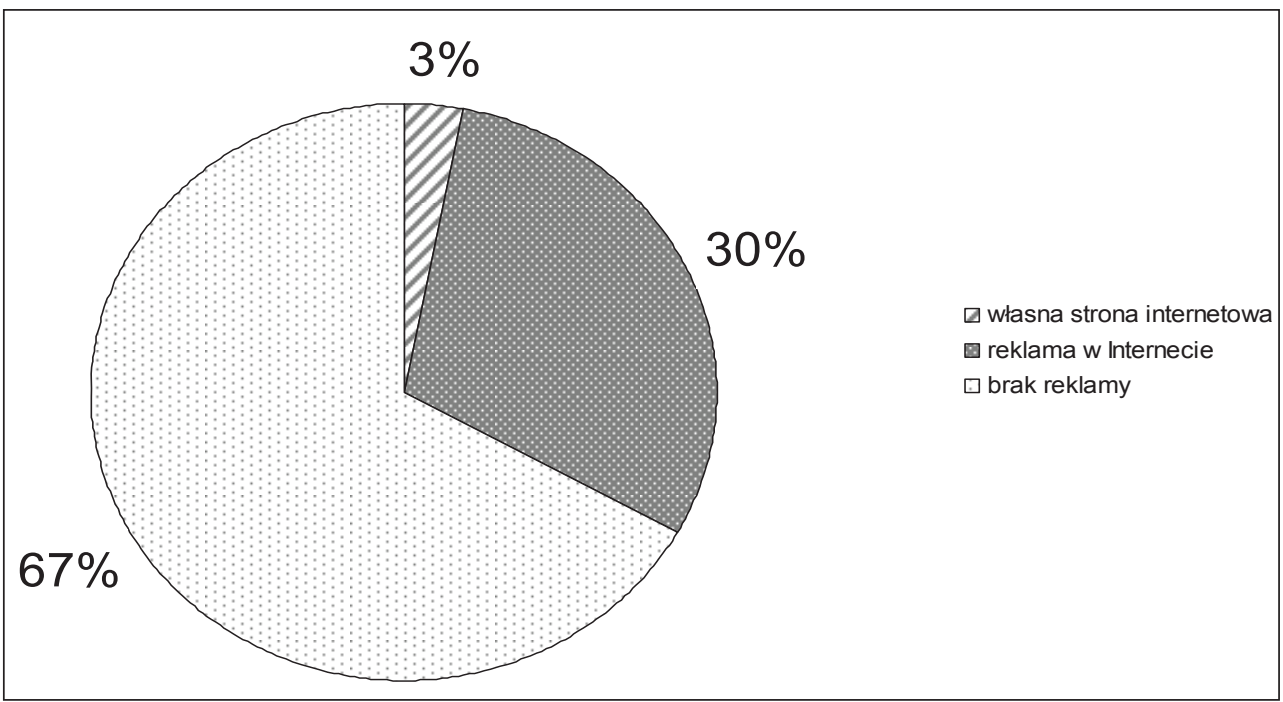

Ryc. 16. Wykorzystanie sieci Internet do reklamy produktów

Źródło: opracowanie autorki na podstawie danych z badań własnych 
Przedsiębiorstwa potrzebują infrastruktury informatycznej dla rozwoju swojej działalności. W dobie nowoczesnych technologii Internet staje się instrumentem umożliwiającym dotarcie z ofertą do globalnego klienta. Strony internetowe otwierają możliwość prezentacji oferty, reklamy czy kontaktu z kontrahentami. Systemy komputerowe umożliwiają sprawne zarządzanie danymi i zasobami, a to z kolei wpływa na efektywność pracy przedsiębiorstwa. Infrastruktura informatyczna może stać się katalizatorem rozwoju firmy, zwiększając jej zasięg działania.

\section{Literatura}

Godlewska-Majkowska H., 2006, Rewitalizacja w procesie rozwoju regionów przemystowych, [w:] Edukacja jako czynnik rozwoju regionów rewitalizowanych, Instytut Funkcjonowania Gospodarki Narodowej, t. XCVI, Szkoła Główna Handlowa, Warszawa.

Świerczewska-Pietras K., 2007, Przedsiębiorczość w sieci. Rola przedsiębiorczości w aktywizacji gospodarczej, Zakład Przedsiębiorczości i Gospodarki Przestrzennej Instytutu Geografii, Akademia Pedagogiczna w Krakowie.

„Społeczeństwo informacyjne w Polsce”, wyniki badań statystycznych z lat 2004-2007, Główny Urząd Statystyczny, Warszawa 2008.

„Stan małych i średnich przedsiębiorstw na Zabłociu” CEM Instytut Badań Rynku i Opinii Publicznej, Kraków czerwiec 2008.

Raport o stanie miasta 2006, Kraków 2007.

\section{Investments in the information technology infrastructure of business entities operating in the post-industrial area included in the Local Revitalization Programme for Zabłocie in Krakow}

A condition for building up companies' potential in the period of dynamic economic development is creating solutions which influence their competitiveness. In the era of new technologies - in which time plays a crucial role in the contact with clients, sale of services or data transfer - computers, the Internet and technologically advanced computer systems supporting enterprise management are becoming an indispensable element of the functioning of the SME sector.

mgr Katarzyna Świerczewska-Pietras

Uniwersytet Pedagogiczny im. Komisji Edukacji Narodowej w Krakowie

Instytut Geografii

Zakład Przedsiębiorczości i Gospodarki Przestrzennej

e-mail: kasiaswierczewska@tlen.pl 